\title{
The State's Responsibility in Forest Fires in Indonesia
}

\section{Muhammad Arifin}

University of Muhammadiyah Sumatera Utara, Medan, Indonesia

Email: muharifin@umsu.ac.id

\begin{abstract}
:
The problem of forest fires becomes a complex problem and even impacts not only the domestic sphere, but also has an impact on foreign countries (neighbors). This problem arises not only due to natural factors, but also due to human factors. This is an extraordinary crime, which is constitutionally the responsibility of the state. This study aims to analyze how the concept of state responsibility in the issue of forest fires in the case approach and the concept of green constituency. The method used in this research is normative legal research premises library research data collection methods. Which shows that the government in the case of forest fires is constitutionally responsible, because Indonesia adheres to the concept of green constitution which reinforces the ecological position in the development of the nation and state.

Keywords:

responsibility; forest fire; Indonesia
\end{abstract}

\section{Introduction}

The public in a number of regions were horrified by the presence of concentrated smoke caused by forest and land fires (karhutla) and even made Siak IV Bridge in Riau Province seem lost from sight. The Karhutla haze in Riau Province is getting thicker and has caused visibility in a number of areas to drop drastically only around 200 to 400 meters. When referenced from hotspot monitoring via Terra / Aqua satellite at 50 percent confidence level, then in Sumatra detected 1,316 hostpots. Of that number, the most was detected in South Sumatra Province with the number 437. Furthermore, Jambi Province had 420 hotspots and Riau Position was detected 279.

Jambi City is one of the 4 regions in Jambi Province which is also hit by haze. Data from the Climatology and Geophysics Meteorology Agency (BMKG) in Jambi said that the haze was the impact of forest and land fires that occurred in Jambi and neighboring provinces of South Sumatra. BMKG satellite monitoring records dated the 18th August 2019 there were 6 hotspots in Jambi Province. Meanwhile, forest and land fire in other areas is still not resolved. The local Meteorology and Climatology and Geophysics Agency (BMKG) even monitored 404 hotspots which were an early indication of forest and land fires being detected in 12 districts and one city in the West Kalimantan region. With the most hot spots in Ketapang Regency, West Kalimantan.

The Ministry of Environment and Forestry (KLHK) stated, based on data collected from January to May 2019, there were 42,740 hectares of forest and burned land. The amount of forest and land burnt is known based on observations of Landsat 8 Operational Land Imager imagery and field monitoring. "Then we also verified and checked the field, until this May we counted 42,740 hectares. Reported on the same page, Riau Province was the location that experienced fire and forest land, which was 27,683 hectares. Next was followed by three other provinces, namely East Kalimantan, Riau Islands and West Kalimantan. "East Kalimantan has 5,153 hectares, Riau Islands has 4,970 hectares, and West Kalimantan has 2,274 hectares. There are at least six provinces that are currently on 
emergency alert for forest and land fires. The six provinces are Riau, West Kalimantan, South Sumatra, Central Kalimantan, South Kalimantan and Jambi.

These forest fires cause increased pollution of smoke-contaminated air. Based on the book Protect Yourself from Haze Hazard Disasters issued by the World Health Organization (WHO) and the Ministry of Health of the Republic of Indonesia, smoke in forest fires contains hazardous substances for health. Based on the Air Pollution Standards Index (ISPU), there are five hazardous contents in forest fire fumes, namely Carbon Monoxide (CO), Sulfur Dioxide (SO2), Nitrogen Dioxide (NO2), and Surface Ozone (O3). Sulfur Dioxide or SO2 is dangerous because it can make the airways shrink and irritate the respiratory mucous membranes.

While Ozone or O3 can irritate the throat. Furthermore, Carbon Monoxide or CO can cause shortness of breath, confusion, chest feels heavy, dizziness, coma to death. Finally, Nitrogen Dioxide or NO2 can damage the organs in charge of cleaning the lungs, so that airway defenses are reduced. If you inhale too much dangerous smoke, the community can potentially be affected by various diseases, such as irritation to chronic lungs.

All of these complex problems are indicated by the actions of entrepreneurs in making new land clearing efforts. Although there are actually many ways of clearing land, clearing land by burning is a relatively easy choice. Clearing land by burning forests is expressly prohibited in the law, which is regulated in Article 69 paragraph (1) letter h of Law Number 32 Year 2009 concerning Environmental Protection and Management (PPLH) which reads: "Everyone is prohibited from doing the act of clearing land by burning. " The criminal threat according to Article 108 of the PPLH Law for those who burn land is a prison term of three years and a maximum of 10 years and a fine of between Rp. 3 billion to Rp. 10 billion.

Protecting the environment and forests is a shared responsibility, therefore the act of burning forests is a form of threat to the survival of the environment. The parties responsible for forest and land fire are those who burn both individuals and corporations. Previously, several parties had filed a material test of Article 69 paragraph (1) letter h of Law 32/2009 which was considered to be inconsistent and counter-productive with the existence of Article 69 paragraph (2) of Law 32/2009 and its explanation, which allowed extensive forest or land burning a maximum of 2 (two) hectares for each head of family to be planted with local varieties and surrounded by firebreaks to prevent the spread of fire to the surrounding area. But the lawsuit has been withdrawn and to date no one has raised an objection to the acquisition of land clearing by burning it.

The crime of burning forests and land is an extraordinary crime (extraordinary crime) so that starting from prevention to handling and enforcement must be done in an extraordinary way as well. Presidential Instruction Number 11 Year 2015 Concerning Improvement of Forest and Land Fire Control should be guided as a reference for preventing and overcoming forest and land fires but prevention fails as well as countermeasures that seem less serious. Therefore, it is actually the state that is responsible for the implications arising from this forest fire case.

State responsibility is a legal concept that is based on the rule of law and the constitution. In legal arrangements, the state must be responsible as contained in the norms of Law Number 32 of 2009, as has happened in the case of Lawsuit in the Palangkaraya District Court Number 118/Pdt.G.LH/2016/PN Plk dated March 22, 2017 which was subsequently 
submitted An appeal to the Palangka Raya High Court Number 36 / PDT / 2017 / PT PLK, which was adjourned was rejected on 19 September 2017. What was then done was Cassation with Number 3555 K / PDT / 2018 which was decided on 16 July 2019. Apart from that, the constitutional concept Indonesia, which adheres to the concept of "Green Constitution", is a reproach of strengthening the protection of the right to a healthy environment for citizens.

\section{Research Method}

In accordance with the problem under study, this research is a legal research (legal research). Istanto, said that legal research is research that is applied or applied specifically to the science of law. In line with Istanto, Marzuki said that legal research is a process to find the rule of law, legal principles, and legal doctrines to answer the legal issues at hand.

This type of research used in this paper is library research. Library research means research that uses written documents as data, and data sources used in this study include primary legal materials, secondary legal materials and tertiary materials. Primary legal material is legal material that is binding or that makes people obey the law, including legal products that are subject to study and legal products as a tool of criticism. Secondary legal materials include explanations of primary legal materials in the form of expert doctrines found in books, journals, and on websites.

\section{Discussion}

\subsection{History of Forest Fires in Indonesia}

In the historical context, forest fires in Indonesia as a dark experience can be seen in the historical track record of Indonesian forest fires. In the Pre-Independence period, forest fires became a problem in the government. This is a concern and is the basis of several basic rules (ordinances) both by the Dutch Government and the kingdom. Some of these rules include: (i) forest ordinance for Java and Madura in 1927 Article 20, (ii) Provinciale Bosverordening Midden Java Article 14, (iii) Rijkblad-Soerakarta Ongko 11 in 1939.

Apart from that, the use of fire in the history of the archipelago is evident through the remains of a burnt pile of vegetation in tropical rain soils that were estimated hundreds of years ago. Historical records also, Steenis and Schippers-Lammertse mention that around 1870 recorded primary forest loss was recorded due to populations that were plundered with human activities. This can be seen as a problem so that several regulations related to forest fires have emerged as a result of these problems.

During Independence, large-scale forest fires occurred in Indonesia because of the heat wave period (El-Nino). In 1982 to 1983, a long drought in East Kalimantan triggered a forest fire that devastated 3.2 million hectares of land with a loss of more than 6 Trillion Rupiah. In 1987 there were 66,000 hectares of burned land despite the fact that the burned land was ten times more extensive than the official data. In 1991, forest fires occurred at 500,000 with reports of local haze. 


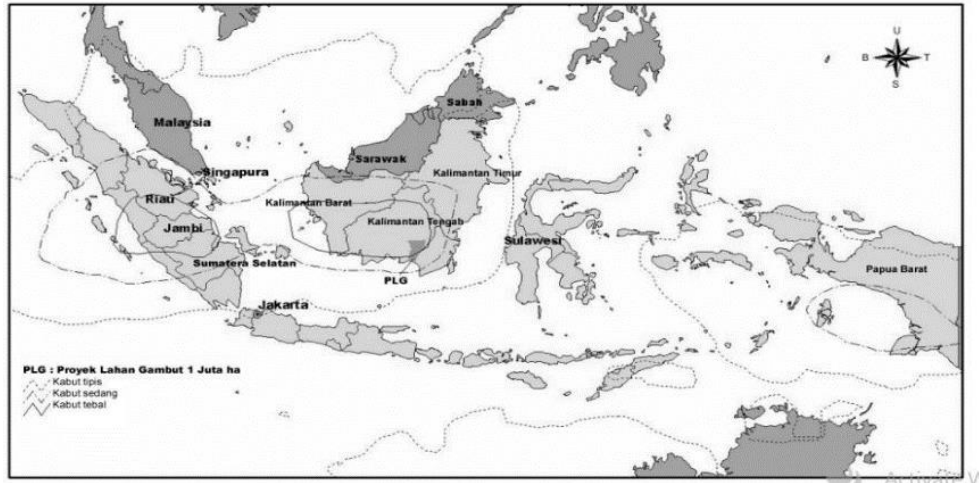

Figure 1. Map of the Distribution of Smoke Haze Due to Forest Fires in 1997-1998

(Barber and Schwelthelm (2000) in Tacconi, 2003)

The next largest forest fires occurred in 1997/1998 in which Indonesia was hit by droughts and fires that occurred throughout the islands of Sumatra and Kalimantan which resulted in forest degredation and economic costs of USD 1.62-2.7 billion. An important note in this incident is the emergence of awareness and care responses both nationally and internationally for controlling forest fires.

\subsection{Policy Analysis and Government Capability in Forest Fire Management}

Improved control of forest and land fires as the legal basis (policy) of the government in terms of preventive efforts and government incentives to cope with the disaster of forest fires, which are regulated in paying the Presidential Instruction Number 11 of 2015 concerning Improvement of Forest and Land Fire Control which is an improvement from the previous Inpres, namely Presidential Instruction Number 16 of 2011. The two regulations must have changed due to the push for more complex and better norms loading. Disparity in loading the norm can be seen in several ways, namely the expansion of the institutions involved and the functions of the institution.

In Presidential Instruction Number 16 of 2011, the government agencies involved were the Coordinating Minister for People's Welfare, the Minister of Forestry, the Minister of Agriculture, the Minister of Environment, the Minister of Research, Technology and Higher Education, the Minister of Home Affairs, the Minister of Finance, the Head of Bappenas, the Attorney General, the TNI Commander, the National Police Chief, the Head of the BNPD , Governor, Regent / Mayor. Whereas at Presidential Instruction 11 of 2015, there were additional ministries and related institutions, namely the addition of the Coordinating Minister for Human Development and Culture, the Minister of Foreign Affairs, the Minister of Health, the Ministry of Education and Culture, the Ministry of Social Affairs and the Ministry of Communication and Information, the Ministry of SOEs, the Ministry of Agriculture and the Ministry of Public Works and Public Relations BMKG.

At the level of expansion of the tasks and functions of the institution, the Ministry of Forestry was previously separated from the Ministry of Environment to coordinate the implementation of forestry and forestry control, monitor permit holders and engage in law enforcement. And the addition was made to expand coordination of environmental restoration due to forest and land fires, increase technical assistance for regional and international cooperation. The Menristek which previously coordinated in the assistance of preventing and suppressing artificial rain techniques. Getting the expansion of authority is an additional aspect of education so that the learning process is not disrupted and empowering 
lecturers and medical students in handling health problems due to forest and land fires. Whereas the Governor / Regent who previously drafted a Regional Regulation related to forest and land fires, optimized the BPBD, required agricultural business actors to have sarpras and sanctioned land burners, added the task of allocating a budget for forest and land fire control.

\subsection{State Responsibility and Green Constitution Analysis}

Settlement of environmental disputes through courts or litigation, namely efforts to prosecute perpetrators of environmental violations / crimes to the court to be tried, especially cases of damage and pollution and environmental damage that cause widespread impacts on the environment and society in general, and the impact is difficult to overcome. Settlement of environmental disputes through the court can be reached through the filing of a civil suit, administrative suit and / or through filing a criminal suit.

Civil environmental disputes begin with a lawsuit filed by parties who feel disadvantaged against the occurrence of environmental damage and / or pollution. This lawsuit is filed through a general court with the intention of demanding compensation to the person responsible for the business and / or activity that causes environmental damage and / or pollution. The obligation of the party responsible for a business and / or activity to pay compensation for damage and / or environmental pollution is regulated in Article 87 of the UUPPLH. However, in more depth, state responsibility can be seen holistically in the concept of green constitution adopted by the 1945 Constitution.

The concept of the Green Constitution has been adopted by several constitutions in the world such as Ecuador in 2008 and the French Constitution in 2005. In Indonesia, the concept is contained in the constitutional provisions of Article $28 \mathrm{H}$ paragraph (1) and Article 33 paragraph 4 of the 1945 Constitution. Rights in the development of human rights doctrine firmly divided into three generations according to Karel Vasak, namely: first, the generation of human rights focuses on civil and political rights, secondly, the generation of human rights focuses on economic, social and cultural rights, third, human rights focuses on the rights of development, with different characteristics. This provides a reflection on the rationale for the emergence of collective rights that are recognized in the third generation of human rights, including the limits on the use of the environment.

International awareness regarding third generation rights is evident in the series of conferences, such as the Stockholm Conference in Sweden, in the framework of the management of the Second World Development Supervisory (1970-1980), Rio de Jenerio Conference 1992, Johannesburg Conference 2002, and the Rio + 20 Conference on 2012, which indirectly has the consequence of building commitments in the country's obligation to make national environmental protection arrangements in response to the decline in environmental functions.

In Indonesia, the concept of green constitution is contained in Article $28 \mathrm{H}$ paragraphs 1 and 34 paragraph 4 which illustrates that environmental development is an integral part of environmental conditions that support the creation of sustainable development as Otto Soemarwoto argues that development must be ecologically, socially and economically sustainable. And Emil Salim stated that development requires the management of natural resources as rational as possible, so that a development approach with environmental development is needed. 
With this regulation, the constellation of national environmental regulation changes. The description is associated with state power or sovereignty over the highest authority of the concept of nomocracy and democracy combined into an environmental concept that has its own autonomy and sovereignty, with the term ecocracy or ecological sovereignty.

Furthermore, Jimly explained in the Ecuadorian Constitution in Article 10 of the 2008 Constitution, Article 71 of the Ecuadorian Constitution 2008, and Article 72 of the 2008 Ecuadorian Constitution illustrated that in addition to humans having the status of people, the environment can also be the holder of their own rights and powers. These rights are the same as the rights and powers of the people. In other words, it can be a subject of its own independence. Because if the highest power in the hands of the people is called democracy, then the highest power in the environment is called ecocracy or environmental sovereignty.

In the Indonesian context, the concept of green constitution is reflected in several articles, as follows: first, the emergence of Article $28 \mathrm{H}$ paragraph 1 doctrinally reflects the environmental conditions that the state recognizes, respects and upholds human rights to the environment. Secondly, Article 33 paragraph 4 shows that it is very closely related to the concept of sustainable development, which refers to a sustainable and environmentally sound national economy.

More concretely, the interpretation of green constitution is elaoraaatif in Law Number 32 of 2009 concerning Environmental Protection and Management, which in Article 44 states that the Law mandates the drafting of legislation both at national and regional levels to pay attention to the protection of environmental dungs life and the principles of life protection and management.

At the level of implementation, the concept of green constitution as a reflection of guarantees of constitutional rights to the environment is sustainable, can be seen in several indicators, namely: first, legal indicators that reflect synchronization and harmonization of green constitutional guarantees that are integral to the right to sustainable environmental development, second, implementing indicators legal practices, namely parties who are held hostage to interests, desires, and power in law enforcement against environmental crimes, third, community indicators, where people have expected and desired fulfillment of guarantees of environmental constitutional rights, fourth, cultural indicators. All of which must be implemented integrally with the concept of green constitution in the context of national and regional environmental protection and respect.

In the context of forest fires caused by certain elements in the life of the state, the state in terms of environmental protection has constitutional duties and authority in carrying out law enforcement as a last resort and preventive-preventive measures as preventive measures. This is not a task that comes down from the vision and mission of the president alone, but it is a constitutional mandate of the 1945 Constitution which must and must be carried out by the government. In more concrete cases, we can see in the Forest Fire case that occurred in Palangkaraya where in this right the president was legally convicted in Case Number 118 / Pdt.G.LH / 2016 / PN Plk on March 22, 2017 which was then submitted to the Appeal to Palangkaraya High Court Number 36 / PDT / 2017 / PT PLK, which was adjourned was rejected on 19 September 2017. What was then done was Cassation with Number 3555 K / PDT / 2018 which was decided on 16 July 2019. 


\subsection{Conservation Efforts and Recommendations}

Considering the massive losses and implications of the forest fires, it is a ladder to do conservation efforts in terms of preventing, handling and overcoming these forest fires. The efforts made by the government so far in terms of prevention are (a) strengthening institutions by establishing sub-directorates of forest fires (b) completing software in the form of technical guidelines for prevention and prevention, (c) completing hardware in the form of preventive equipment, (d) conducting training in control forest fires, (e.) campaigns and outreach through various apples to control forest fires ( $f$ ) provision of provisions to entrepreneurs and regional forestry ministry chiefs, $(\mathrm{g})$ in approval of area expulsion required to clear forests without burning.

Whereas in terms of countermeasures, the government made efforts to (a) empower fire posts at all levels, (b) mobilize all resources aligned with the ministry of forestry, (c) increase coordination through pusdalkarhutlapus and pusdalkarhutlada, (d) request foreign assistance to extinguish forest fires.

Apart from that, in the context of domestic handling from the environmental and health aspects, which technically through blackout of smog itself as provoked by South Sumatra, using two Cassa aircraft through the Weather Modification Technology (TMC) in the air of South Sumatra. By spreading seven tons of salt on 374 hectares, reducing fires to as much as $55 \%$ of land which is oil palm, $31 \%$ of community land, $14 \%$ of forest area with a total of 374 hectares. Other preventive measures include preparing water bags, making SOPs responsive to handling smoke and preparing technicians professionally.

Whereas in the legal and institutional aspects as a media for law enforcement in the case of legal fires, the government strengthens the policy through the regulation of Law Number 32 of 2009 concerning Environmental Protection and Management in Chapter XV Article 98 paragraph 1 states that anyone who intentionally commits an act which results in exceedance of ambient air quality standards, water quality standards, seawater quality standards or environmental damage standard criteria, punishable by imprisonment for a minimum of 3 years and a maximum of 10 years, and a minimum of 3 billion and a maximum of 10 billion.

While in the Decree of the Minister of Environment No. 30 of 1999, states the obligation for business entities that are considered to have the potential to pollute the environment to compile environmental management documents, the purpose of which is as a tool / instrument binding for the responsibility of a business / activity to carry out environmental management and monitoring in an efficient directed manner and effective.

\section{Conclusion}

Forest fires caused by human and non-human factors (natural activities) have impacts across sectors, namely the health, environment, economy and transportation sectors. In the context of government policies and capacities in overcoming forest fires, the government has issued various policies through Presidential Instruction Law Number 11 of 2015 concerning Improvement of Forest and Land Fire Control which comprehensively constructs institutions and their authority in forest and land fire prevention.

The state's responsibility in the matter of forest fires is a consequence of the Indonesian Law State which adopts the concept of green constitution in which 
environmental development is an integral part of the right to the environment that supports the creation of ecologically sustainable development as stipulated in Article $28 \mathrm{H}$ paragraph 1 of the 1945 Constitution. Whereas in conservation efforts can be made in terms of prevention and prevention of forest and land fires.

\section{References}

Andrey Sujatmoko. 2014. Hukum HAM dan Hukum Humaniter, Jakarta: RajaGrafindo Persada.

Anih Sri Suryani. 2012, Penanganan Asap Kabut Akibat Kebakaran Hutan di Wilayah Perbatasan Indonesia. Jurnal Aspirasi.

Emil Salim. 1993. Pembangunan Berwawasan Lingkungan, Jakarta: Penerbit LP3ES.

I Dewa Gede Atmadja. 2011. Demokrasi, HAM dan Konstitusi, Malang: Setara Press.

I Putu Cakabawa Landra, 2015, Buku Ajar dan Klinik Manual Hukum Lingkungan, Denpasar: Udayana University Press.

I Gede, Yusa and Bagus Hermanto, 2018, Implementasi Green Constitution di Indonesia: Jaminan Hak Konstitusional Pembangunan Lingkungan Hidup Berkelanjutan, Jurnal Konstitusi Vol.15, Nomor 2

Jimly Asshiddiqie, 2009, Gagasan Kedaulatan Lingkungan: Demokrasi versus Ekokrasi, dari buku Green Constitution, Jakarta: RajawaliGrafindo Persada

Koesnadi, 2005, Hukum Tata Lingkungan, Yogyakarta: Gajah Mada University Press.

NHT Siahaan, 2004, Hukum Lingkungan dan Ekologi Pembangunan, Jakarta: Erlangga.

Syamsuharya, Bethan, 2008, Penerapan Prinsip Hukum Pelestarian Fungsi Lingkungan Hidup dalam Aktivitas Industri Nasional, Bandung: Alumni.

Maret Priyatna, 2010, Penerapan Konstitusi Hijau di Indonesia sebagai Tanggungjawab Negara dalam Perlindungan dan Pengelolaan Llingkungan Hidup. Jurnal Konstitusi Vol.7, No.4.

Subandi. (2011). Ekonomi Pembangunan. Bandung: Alfabeta.

Sugiyono. (2012). Metode Penelitian Kualitatif. Bandung: Afabeta.

Thoha, Miftah. (2010). Kepemimpinan Dalam Manajemen. Jakarta: Rajawali Pers.

Undang-Undang Nomor 9 tahun 2015 tentang perubahan kedua Undang-Undang Nomor 23

Tahu 2014 tentang Pemerintahan Daerah

Undang-Undang Nomor 23 Tahun 2014 tentang Pemerintah Daerah

Undang-Undang Pemerintah Aceh Nomor 11 Tahun 2006. Tentang Pemerintah Aceh.

Undang-Undang Republik Indonesia Nomor 1 Tahun 2011. Tentang Perumaban dan Kawasan Permukiman. 